\title{
Rett syndrome: the Brazilian contribution to the gene discovery
}

\author{
Síndrome de Rett: a contribuição brasileira para a descoberta do gene \\ José Luiz Pinto PEREIRA1,2,3, José Luiz PEDROSO4 , Orlando G. P. BARSOTTINI'4, Alex Tiburtino MEIRA5, \\ Hélio A. G. TEIVE
}

\begin{abstract}
A brief history of the syndrome discovered by Andreas Rett is reported in this paper. Although having been described in 1966, the syndrome was only recognized by the international community after a report by Hagberg et al. in 1983. Soon, its importance was evident as a relatively frequent cause of severe encephalopathy among girls. From the beginning it was difficult to explain the absence of male patients and the almost total predominance of sporadic cases (99\%), with very few familial cases. For these reasons, it was particularly difficult to investigate this condition until 1997, when a particular Brazilian family greatly helped in the final discovery of the gene, and in the clarification of its genetic mechanism. Brief references are made to the importance of the MECP2 gene, 18 years later, as well as to its role in synaptogenesis and future prospects.
\end{abstract}

Keywords: Rett syndrome; brain diseases; genes.

\section{RESUMO}

Uma breve história de uma síndrome neurológica descoberta por Andreas Rett é relatada neste artigo. Embora tenha ocorrido em 1966, a síndrome só foi reconhecida pela comunidade internacional após um relato de Hagberget al, em 1983. Logo, sua importância ficou evidente como causa relativamente frequente de encefalopatia grave entre as crianças do sexo feminino. Desde o início, foi difícil explicar a ausência de envolvimento de pacientes do sexo masculino e a quase absoluta preponderância de casos esporádicos (99\%), com muitos poucos casos familiares. Por essas razões, foi difícil investigar essa condição até 1997, quando uma família brasileira em particular ajudou muito na descoberta final do gene e no esclarecimento de seu mecanismo genético. São feitas referências sucintas à importância do gene MECP2, dezoito anos depois, bem como ao seu papel na sinaptogênese e nas perspectivas futuras.

Palavras-chave: Síndrome de Rett; encefalopatias; genes.

Rett syndrome, which was described 52 years ago in Vienna, Austria, by Andreas Rett, a pediatrician, is caused by a heterozygous mutation of the MECP2 gene located in the distal region of the $\mathrm{X}$ chromosome, which encodes a MECP2 protein, or methyl-CpG 2 binding repressor protein, which binds to methylated $\mathrm{DNA}^{1,2}$. This is a protein with two isoforms, preferentially expressed in the brain, regulating the synaptogenesis process. Approximately $80 \%$ of the time this mutation is found with the classic phenotypes, but mutation of the gene can also occur in $50 \%$ of the cases of atypical phenotypes or mild forms of the syndrome; X-linked non-random inactivation might explain most of this clinical variability. The MECP2 is a small gene, with only four exons, two of them being coding exons ( 3 and 4). ${ }^{1,2}$ Hundreds of mutations have been identified, $54 \%$ of them are related to causing Rett syndrome. This gene has the function of silencing others, regulating the synaptogenesis process in the infant brain, which peaks in the first two years of life - when the classic syndrome is expressed clinically as stagnation and even regression of neurological or psychomotor development. Rett syndrome is

\footnotetext{
${ }^{1}$ Prefeitura Municipal de Curitiba, Serviço de Atendimento Móvel de Urgência (SAMU), Curitiba PR, Brasil;

${ }^{2}$ Hospital John Hopkins, Investigações Genéticas (1999-2000), EUA;

${ }^{3}$ Instituto Kennedy Krieger, Investigações Genéticas (1999-2000), EUA;

${ }^{4}$ Universidade Federal de São Paulo, Departamento de Neurologia, São Paulo SP, Brasil;

${ }^{5}$ Universidade Federal do Paraná, Departamento de Medicina Interna, Serviço de Neurologia, Curitiba PR, Brasil.

José Luiz Pedroso iD http://orcid.org/0000-0002-1672-8894; Orlando G. P. Barsottini iD https://orcid.org/0000-0002-0107-0831;Alex Tiburtino Meira

iD https://orcid.org/0000-0002-6685-7491; Hélio Afonso Ghizoni Teive iD https://orcid.org/0000-0003-2305-1073

Correspondence: Hélio A. G. Teive; Universidade Federal do Paraná, Departamento de Medicina Interna, Serviço de Neurologia, Curitiba PR, Brasil; R. Gen.

Carneiro, 181 - Alto da Glória, Curitiba - PR, 80060-900; E-mail: teiveads@mps.com.br

Conflict of interest: There is no conflict of interest to declare.
}

Received 07 November 2018; Received in final form 04 March 2019; Accepted 20 March 2019. 
a sexually-dominant disease, much more common in females and extremely rare in males ${ }^{1,2}$. In this historical review we discuss the Brazilian contribution to the discovery of the gene of Rett syndrome.

\section{ANDREAS RETT - A SHORT BIOGRAPHY}

A medical aphorism teaches students and professionals that in the act of diagnosing and treating, more than the examination or technological resources, the clinic diagnosis is paramount. Andreas Rett (Figure 1), working at the Boltzman Institute in Vienna, based on isolated clinical patients, described what appeared to be a disease seen exclusively in females. His reasoning was initially based on only 22 young women ${ }^{3,4}$. We now know that Rett syndrome has also been described in male patients, but they are very rare and present with a more severe phenotype. Andreas Rett was born in Furth, Bavaria, on January 2, 1924 and studied medicine at the University of Innsbruck (Austria) and Bonn (Germany). After receiving his medical degree, he specialized in developmental pediatrics and began to practice in Vienna, where he worked until the end of his life $\mathrm{e}^{3,4}$. In the clinic, he mostly focused on examining and treating children who had developmental delay or special educational needs. He was a great clinician, whose considerable

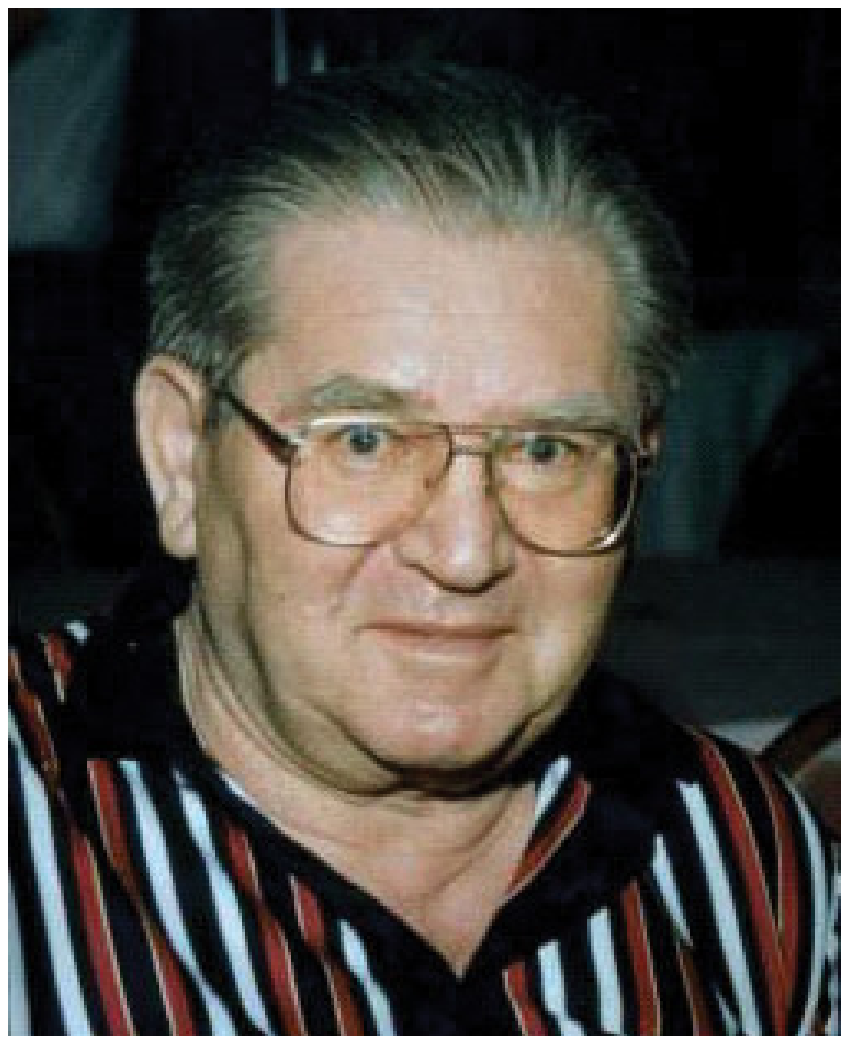

Figure extracted from http://www.aeiou.at/aeiou.encyclop.data.image.r/ r539792a.jpg, accessed March $4^{\text {th }}, 2019$.

Figure 1. Andreas Rett (1924-1997). capacity for observation allowed him to identify a new neurological entity, later coined Rett syndrome. Nowadays, this has been recognized as a cause of physical and mental impairment in girls (1/10,000 female births). The syndrome was named Rett syndrome by Bengt Hagberg (Figure 2) in a seminal article, in $1983^{5}$.

\section{RETT SYNDROME - THE DEFINITION OF THE SYNDROME}

In this syndrome, girls, as described by Rett, had a very typical condition and progression: a normally-born child with no history of gestational or obstetric events, families with no histories of other cases, or even those with other genetic disorders, who presented with developmental delay between six months and two years of age; this occurs mainly because de novo pathogenic variants occur much more frequently in male gametogenesis ${ }^{1,2,3,4}$. In the original description, patients also presented with peculiar and typical involuntary movements with their hands: the Rett-type manual stereotypic movement disorders. Nowadays, it is known that this phenotype occurs in other disorders, such as FOXG1- and CDKL5-associated encephalopathy, and many others $^{6,7}$. In 1966, Rett described this clinical condition in German $^{3}$, in a periodical of limited circulation, presenting an English version only in $1977^{4}$. However, it took a long

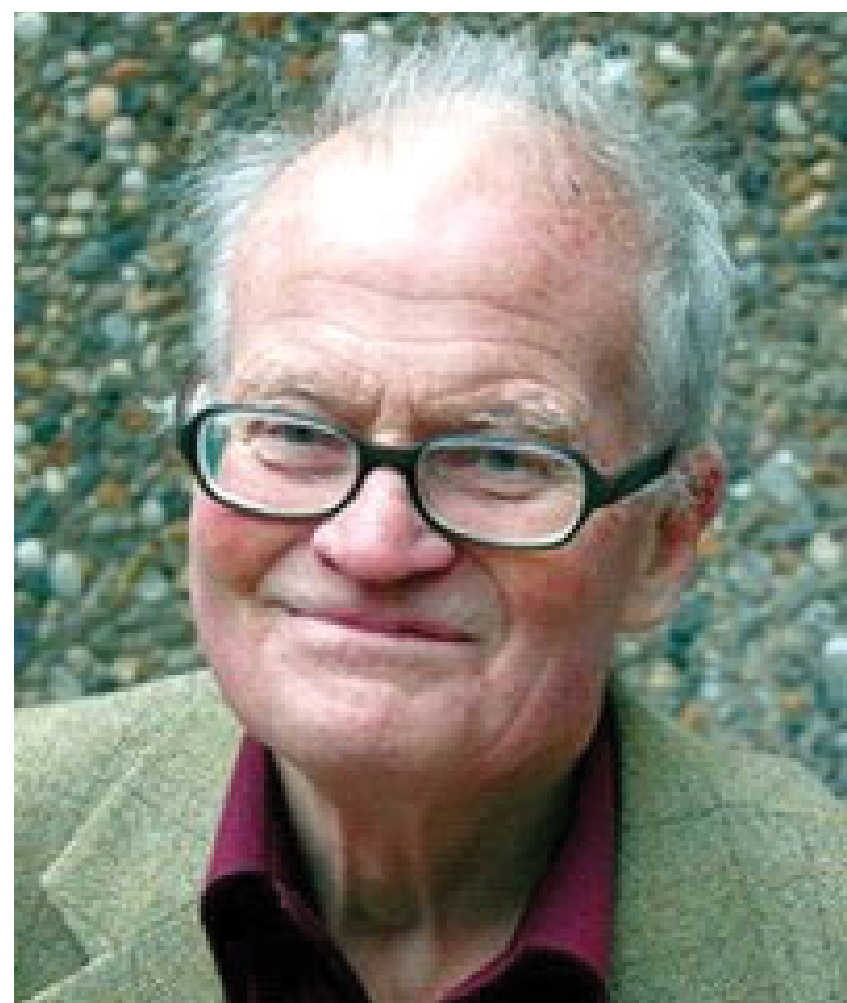

Figure extracted from https://tidsskriftet.no/2015/09/legelivet/minneord-2 accessed March $4^{\text {th }}, 2019$.

Figure 2. Bengt Hagberg (1923-2015). 


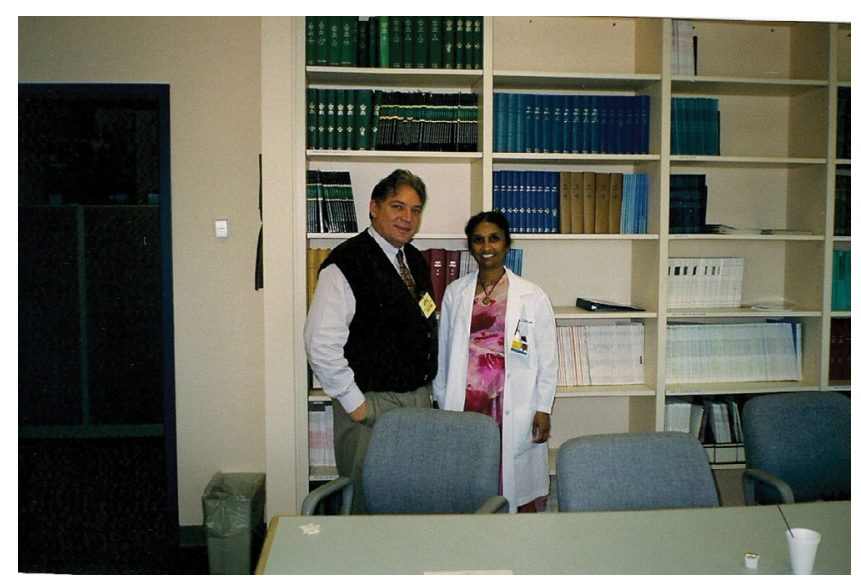

Figure 3. Dr. SakkuBai Naidu and Dr. Pereira (JLPP, personal archive, with permission).

time for this content to circulate among peers in the community of child neurologists and neurologists in Europe $e^{1,3,4}$. In 1983, Hagberg et al. ${ }^{5}$ published a report on 35 patients. From then on the neurological community of Europe and the USA gradually recognized the syndrome. Although Rett syndrome typically occurs in females, pathogenic mutation in MECP2 in males usually does not have the Rett syndromelike phenotype but instead presents with a severe epileptic encephalopathy, with hypotonia and apnea. The exception to the previous statement is males with Klinefelter syndrome (47, XXY), which also has a Brazilian contribution ${ }^{8,9}$.

\section{Rett syndrome, genetic studies, and the Brazilian contribution}

SakkuBai Naidu (Figure 3) and Hugo Moser, from the Kennedy Institute, promoted the first American conference on Rett syndrome in 1986, where they reported on the natural history of 70 patients $^{10,11}$. In Brazil, in 1987, Sergio Rosemberg et al. reported on the analysis of the first five Brazilian patients ${ }^{12}$. In 1991, linked to the International Rett Syndrome Association, the Paraná region of the Brazilian Rett Syndrome Association was founded in Curitiba, when the diagnoses of some patients were recognized. Subsequently, a monograph on 12 Brazilian patients was written ${ }^{13}$. One family had three affected siblings (Figure 4). It was known that, in international literature, no more than a dozen familial cases (full-sisters or half-sisters) had been reported, among more than 3,000 sporadic cases $^{1,2,5}$. The case histories of the three patients were presented at a medical conference on the syndrome in Gothenburg, Sweden, in $1996^{14}$. On this occasion, DNA samples of the three Brazilian girls

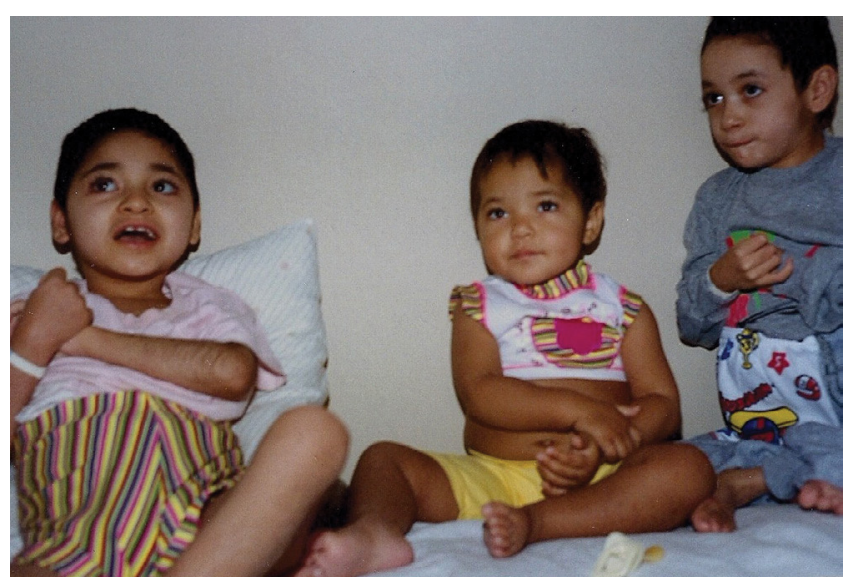

Figure 4. Three Brazilian sisters with classical Rett syndrome, who participated in the study that enabled the description of the MECP2 gene as the genetic cause of the disease (1997, JLPP, personal archive, with permission of the author and the patient's family).

and their parents were also forwarded by Dr. José Luiz Pinto Pereira (Figure 3) to other groups of geneticists in London and Stockholm. SakkuBai Naidu, a neurogeneticist at the Kennedy Institute, had been studying the syndrome at Johns Hopkins Hospital for more than a decade and was interested in this family with three affected sisters, a unique case now known worldwide. In order to make further research possible, in October 1997 the patients were moved to Baltimore. Initially, Naidu et al. published the chromosome mapping of Rett syndrome and a candidate region on the telomere of $\mathrm{Xq}^{10}$ in collaboration with geneticists from Stockholm and London. Soon after, the confirmation of the genetic locus in Xq2.8 ${ }^{15}$ was also published by Sirianni et al. ${ }^{16}$, including Dr. Pereira (a neuropediatrician) and Professor Pilotto (a geneticist and professor at the Federal University of Paraná). In this manner, not only could the gene locus be confirmed, but it was also possible to demonstrate that the DNA sequences were inherited by the affected children from the mother and were not shared in the same chromosomal subregion by their normal sisters ${ }^{16}$. Finally, in the same year, another group of geneticists led by Dr. Hudha Zoghbi, with Dr. Uta Francke as a collaborator, both from the Howard Hughes Medical Institute, Baylor College of Medicine, made the final discovery of the gene, leading to further publications ${ }^{17,18}$. In these publications, the participation of the Brazilian family, with three affected sisters, was highly relevant to the discovery of the Rett syndrome gene. In conclusion, these three Brazilian sisters made an enormous contribution to the genetic description of the MECP2 as the cause of Rett syndrome.

\section{References}

1. Leonard H, Cobb S, Downs J. Clinical and biological progress over 50 years in Rett syndrome. Nat Rev Neurol. 2017 Jan;13(1):37-51. https://doi.org/10.1038/nrneurol.2016.186
2. Shah RR, Bird AP. MeCP2 mutations: progress towards understanding and treating Rett syndrome. Genome Med. 2017 Feb;9(1):17. https://doi.org/10.1186/s13073-017-0411-7 
3. Rett A. [On a unusual brain atrophy syndrome in hyperammonemia in childhood]. Wien Med Wochenschr. 1966 Sep;116(37):723-6. German.

4. Rett A. Cerebral atrophy associated with hyperammonemia. In:Vinkin PJ, Bruyn GW, editors. Handbook of Clinical Neurology. Amsterdam: North Holland; 1977. p. 305-29.

5. Hagberg B, Aicardi J, Dias K, Ramos O. A progressive syndrome of autism, dementia, ataxia, and loss of purposeful hand use in girls: Rett's syndrome: report of 35 cases. Ann Neurol. 1983 Oct;14(4):4719. https://doi.org/10.1002/ana.410140412

6. Ma M, Adams HR, Seltzer LE, Dobyns WB, Paciorkowski AR. Phenotype differentiation of FOXG1 and MECP2 Disorders: a new method for characterization of developmental encephalopathies. J Pediatr. 2016 Nov;178:233-240.e10. https://doi.org/10.1016/j.jpeds.2016.08.032

7. Bahi-Buisson N, Bienvenu T. CDKL5-Related disorders: from clinical description to molecular genetics. Mol Syndromol. 2012 Apr;2(3-5):137-52. https://doi.org/10.1159/000331333

8. Schwartzman JS, Souza AM, Faiwichow G, Hercowitz LH. [Rett phenotype in patient with XXY karyotype: case report]. Arq Neuropsiquiatr. 1998 Dec;56(4):824-8. Portuguese. https://doi.org/10.1590/S0004-282X1998000500020

9. Schwartzman JS, Bernardino A, Nishimura A, Gomes RR, Zatz M. Rett syndrome ina boy with a 47,XXY karyotype confirmed by a rare mutation in the MECP2 gene. Neuropediatrics 200;32(3):162-4. https://doi.org/10.1055/s-2001-16620

10. Naidu S, Murphy M, Moser HW, Rett A, Opitz JM, Reynolds JF. Rett syndrome: natural history in 70 cases. Am J Med Genet Suppl. 1986;1 S1:61-72. https://doi.org/10.1002/ajmg.1320250507
11. Murphy M, Naidu S, Moser HW, Opitz JM, Reynolds JF. Rett syndrome: bservational study of 33 families. Am J Med Genet Suppl. 1986;1 S1:73-6. https://doi.org/10.1002/ajmg.1320250508

12. Rosemberg S, Arita F, Campos C, Coimbra R, Posadas R, Ellovitch $S$, et al. [Rett syndrome: analysis of the first five cases diagnosed in Brazil]. Arq Neuropsiquiatr. 1987 Jun;45(2):143-52. Portuguese. https://doi.org/10.1590/S0004-282X1987000200007

13. Pereira JS. Síndrome de Rett: uma introdução ao seu diagnóstico clínico e diferencial, e ao planejamento de ações de reabilitação. Curitiba: Secretaria de Estado da Educação; 1992.

14. Three sisters with Classic Rett Syndrome. In: Annals from World Congress on Rett Syndrome; 1996 Aug 30th-Sep 1st; Sweden. Gothenburg: Springer. Eur Child Adolesc Psychiatry. 19976 Suppl 1: 1-108.

15. Xiang F, Zhang Z, Clarke A, Joseluiz P, Sakkubai N, Sarojini B, et al. Chromosome mapping of Rett syndrome: a likely candidate region on the telomere of Xq. J Med Genet. 1998 Apr;35(4):297-300. https://doi.org/10.1136/jmg.35.4.297

16. Sirianni N, Naidu S, Pereira J, Pillotto RF, Hoffman EP. Rett syndrome: confirmation of $X$-linked dominant inheritance, and localization of the gene to Xq28. Am J Hum Genet. 1998 Nov;63(5):1552-8. https://doi.org/10.1086/302105

17. Amir RE, Van den Veyver IB, Wan M, Tran CQ, Francke U, Zoghbi HY. Rett syndrome is caused by mutations in X-linked MECP2, encoding methyl-CpG-binding protein 2. Nat Genet. 1999 Oct;23(2):185-8. https://doi.org/10.1038/13810

18. Wan M, Stephen L, Xianyu Z, Houwink-Manville I, Song H, Amir R, et al. Recurrent spontaneous and familial MECP2 mutation at CpG hotspots. Am J Human Genet. 1999;65(6):1520-9. 